\title{
THE ENVIRONMENTAL COURT PROPOSAL: REQUIEM, ANALYSIS, AND COUNTERPROPOSAL
}

The recent growth and high visibility of what is called "environmental" litigation have prompted serious debate whether a special judicial system should be created to handle such matters. ${ }^{1}$ Several current proposals suggest the creation of a special judicial entity to hear civil actions ${ }^{2}$ of an "environmental" nature. The jurisdiction of the specialized court would be limited to those cases. ${ }^{3}$

Congress sensed the need for reform in this area several years ago. In 1972, it directed that the President, acting through the Attorney General, conduct a full investigation of the feasibility of establishing an environmental court system. ${ }^{4}$ Pursuant to the mandate, the Attorney General prepared three hypothetical judicial systems. The first called for the creation of a court to hear environmental cases generally, with both original and appellate jurisdiction. The court would have exclusive jurisdiction over all cases within its compass. ${ }^{5}$ The second proposal was for the establishment of a court to review all federal agency orders affecting the environment. ${ }^{6}$ The third model would authorize a court to review all orders of designated federal agencies. ${ }^{7}$ All three models assumed that the court would have exclusive jurisdiction and would be created under article III as a constitutional court. ${ }^{8}$ The authors of the Report ultimately decided against rec-

${ }^{1}$ See, e.g., H. R. REP. No. 92-911, 92d Cong., 2d Sess. 143 (1972); Whitney, The Case for Creating a Special Environmental Court System, 14 WM. \& MARY L. REv. 473 (1973) [hereinafter cited as Whitney I].

2 There would be a serious problem in conferring jurisdiction over criminal matters to a specialized court because of the constitutional provision that trial of all crimes shall be held in the state in which the crime was committed. U.S. Const. art. III, § 2. See Report of the President, Acting through the Attorney General, on the Feasibility of Establishing an Environmental Court System II-12 to -13 (1973) [hereinafter cited as REPORT].

${ }^{3}$ See generally RePORT, supra note 2, at II-7 to -12; Rightmire, Special Federal Courts, 13 ILL. L. REv. 15 (1918). Jurisdiction of the United States district courts, the federal courts of general jurisdiction, basically extends to all cases arising under the Constitution, laws, or treaties of the United States. 28 U.S.C. \$\$ 1331-63 (1970).

4 Act of Oct. 18, 1972, Pub. L. No. 92-500, \$9, 86 Stat. 899.

s RePort, supra note 2, at V-1 to -2.

${ }^{6}$ Id.

${ }^{7} I d$.

${ }^{8} I d . \mathrm{V}-3$. 
ommending implementation of any of the proposed models or any similar proposal. ${ }^{9}$

This Comment will examine the problems which impelled the suggestion of a special environmental court and the reasons for its apparent rejection. An alternative system which attempts to solve the problems and at the same time avoids the criticisms aimed at the proposed environmental court system will then be offered.

\section{Benefits of the Proposed Environmental Court System}

\section{A. Uniformity of Law}

One of the principal arguments in favor of establishing a specialized court is that it would increase the uniformity and certainty of the law. ${ }^{10}$ Professor Scott Whitney, one of the chief advocates of a specialized environmental court, ${ }^{11}$ recommended that the new court system be granted exclusive trial and appellate jurisdiction over environmental litigation. ${ }^{12}$ This suggestion follows from his belief that federal environmental law is full of conflicting decisions. He detailed the conflict ${ }^{13}$ by focusing on the varying results reached by courts of appeals in interpreting and enforcing the duties set forth in the National Environmental Policy Act (NEPA). ${ }^{14}$

Supreme Court review is not really a solution to this lack of uniformity. Petitioning for certiorari is simply too costly, and its granting too rare, for it to be an effective tool in the general run of cases. ${ }^{15}$ While the suggestion that a specialized appellate body can solve this problem is seductive, there is nothing in the pro-

${ }^{9} I d$. VIII-1 to -4 . This conclusion was the same as that suggested by the overwhelming consensus of replies to letters sent to government agencies and private organizations soliciting comments on the proposed models. Id. A-1 to $-2, \mathrm{~B}-1$ to -2 .

${ }^{10}$ See Whitney I, supra note 1, at 486-501. See also Griswold, The Need for a Court. of Tax Appeals, 57 HaRv. L. REv. 1153, 1156 (1944).

This argument is generally applied only to the appellate courts. With the exception of the Court of Claims and other single-body judicial structures, the policies favoring ready access to geographically local courts have outweighed the supposed need for uniformity at the trial court level.

"See Whitney, The Case for Creating A Special Environmental Court System-A Further Comment, 15 WM. \& Mary L. Rev. 33 (1973) [hereinafter cited as Whitney II]; Whitney I, supra note 1 .

${ }^{12}$ Whitney I, supra note 1 , at 487 . This corresponds to the Traynor proposal in the tax field. See Traynor, Administrative and Judicial Procedure for Federal Income, Estate, and Gift Taxes-A Criticism and A Proposal, 38 Colum. L. Rev. 1393, 1427-29 (1938).

${ }^{13}$ Whitney I, supra note 1 , at 490-501.

it 42 U.S.C. $\$ \S 4321-47$ (1970).

${ }^{15}$ See Griswold, supra note 10 , at 1156. See also Whitney I, supra note 1, at 486. 
posed structural modification which would guarantee the desired uniformity.

An existing specialized court, the Court of Customs and Patent Appeals, ${ }^{16}$ offers a good testing ground for Whitney's thesis. If his thesis is correct, the law created by that court should possess an admirable uniformity and clarity. A recent study of its functioning indicated, however, that it not only has failed to settle the law, but that it has positively added to the confusion. ${ }^{17}$ Extension of this conclusion suggests that the most that can be said of a specialized environmental court structure is that it would provide the possibility of improvement over the present scheme. The question then reduces to whether the uncertain improvement justifies the structural change. ${ }^{18}$

Furthermore, it is not entirely clear that the legal chaos that Whitney found prevalent in the environmental field really exists. Two other respected commentators argue:

Although notable examples of conflict exist, the overall pattern is one of surprising consistency in the resolution of the difficult policy questions involved in applying environmental laws. More consistency might be desirable, but the small margin of gain hardly seems to justify the establishment of a separate court system. ${ }^{19}$

Even if Whitney's findings are correct, the inclusion of trial courts in the environmental court system raises another problem: whether uniformity at the trial court level outweighs the policies favoring access to geographically local courts.

Regardless of whether trial courts are included in an environmental court system, there is no apparent reason why uniformity of environmental law is more desirable than uniformity

16 The court is empowered only to hear appeals from final judgments or orders of the Customs Court and from certain decisions or findings of the Tariff Commission, the Patent Office, and the Secretary of Commerce. 28 U.S.C. $\$ \$ 1541-44$ (1970).

${ }_{17}$ Metzer \& Musrey, Judicial Review of Tariff Commission Actions and Proceedings, 56 Cornell L. Rev. 285, 339-41 (1971).

${ }^{18}$ The Commerce Court is another example of the rule that structural change in the judicial system does not necessarily lead to the desired results. It was established to expedite litigation, create a body of experts, and harmonize agency decisions-just as the proposed environmental court would be. See RePORr, supra note 2, at B-68 (response of the Interstate Commerce Commission); Dix, The Death of the Commerce Court, 8 AM. J. LEGAL HisT. 238 (1964).

As Nathanson pointed out, specialized courts have not displayed notable mastery of the art of statutory interpretation. Nathanson, The Administrative Court Proposal, 57 VA. L. REv. 996, 1000 n.16 (1971).

${ }^{19}$ Hines \& Nathanson, Preliminary Analysis of Environmental Court Proposal Suggested in the Federal Water Pollution Control Act Amendments of 1972, in REPORT, supra note 2, at C-1, C-16 to -17 (footnotes omitted). 
under any other body of federal law. ${ }^{20}$ Furthermore, it is hard to ignore the argument that "[a]n environmental court would tend to encourage proliferation of other specialized courtssuch as for civil rights, welfare, education, health [and] agriculture ...."21 Our present system tolerates some lack of uniformity among the courts of appeals; it is a fact of life in the federal court system that there will not be total certainty about what the law "is." The remedy, if any, should be a general one, reaching all areas and conflicts.

The policy of developing a unified body of federal environmental law should not constitute a major factor in determining whether an environmental court system should be created. The policy may not be as strong as initial reactions might indicate, and the possibility of improvement is too uncertain to justify the creation of a new judicial body.

\section{B. The Caseload Factor}

Another argument in favor of creating an environmental court system is that our present courts are overburdened, ${ }^{22}$ and that the congestion can be significantly ameliorated by establishing a new judicial body to handle all environmental cases. ${ }^{23}$ The classic statement supporting this position was made by Judge Skelly Wright, who observed that current environmental cases represent "only the beginning of what promises to be a flood of new litigation-litigation seeking judicial assistance in protecting our natural environment." 24

There is, however, serious doubt whether this flood will actually commence. Statistics from the Administrative Office of United States Courts indicate that as of June 30, 1973, there were approximately 845 cases pending in federal courts which could be identified as "environmental," representing less than seven-tenths of one percent of the total federal caseload. ${ }^{25}$

${ }^{20}$ See Carrington, Crowded Dockets and the Courts of Appeals: The Threat to the Function of Review and the National Law, 82 HARv. L. REv. 542, 596-604 (1969). But see text accompanying notes 90-91 infra.

21 Report, supra note 2, at B-8 (response of the American Bar Association).

${ }^{22}$ Cf. Carrington, supra note 20.

23 Whitney II, supra note 11 , at 49.

${ }^{24}$ Calvert Cliffs' Coordinating Comm., Inc. v. AEC, 449 F.2d 1109, 1111 (D.C. Cir. 1971). See also Hanly v. Mitchell, 460 F.2d 640, 642 (2d Cir. 1972).

In direct contrast to these views, some knowledgeable observers believe that the environmental caseload will decrease as the administrative process begins to adjust and becomes more responsive. See, e.g., REPORT, supra note 2, at B-8 (response of the American Bar Association).

${ }^{25}$ REPORT, supra note 2, at III-12. 
It is of course true that large caseloads are not necessary to justify a separate specialized court. For example, only 398 cases were pending in the Court of Customs and Patent Appeals on June 30, 1972. ${ }^{26}$ But while there may not be a large number of "environmental" cases, they do seem to demand an inordinate amount of time and expertise. In support of an environmental court system, the General Services Administration noted:

This agency has been involved in an excess of 400 cases since January 1, 1970. Seven cases involved significant environmental issues. One case involved a minor environmental issue. While this percentage may seem low, these seven cases are among the most significant cases involving this agency and are the most time-consuming and complex. ${ }^{27}$

As a rule, neither numbers nor complexity constitute compelling arguments for creating special courts to ease the burden on the general court system. Unless there is some special quality inherent in a certain class of cases, it would make more sense merely to devote additional resources to the general courts. The environmental cases seem to have such a quality: The problems they present are not soluble by a mere increase in judicial manpower. Rather, the most difficult problems they create involve the courts' lack of technical expertise. This suggests not simply that another entity is needed, but that an expert entity should be created, one that is not daunted by the complexities into which it must plunge.

\section{Expertise}

The bulwark of the proponents of an environmental court system is the thesis that extant courts do not have the expertise to handle environmental litigation efficiently. Whitney argues

not that any federal judge or court . . is not capable, given "world enough and time," to develop a mastery of

${ }^{26} \mathrm{Id}$. III-13. It should be noted in any case that the relevance of these comparative caseload statistics to the environmental court controversy is made questionable by the concentration of much customs litigation around New York City, where the Court of Customs and Patent Appeals sits. Without the specialized court, the District Court for the Southern District of New York would be the forum for a huge number of customs cases. Environmental cases, however, may be expected to arise throughout the country, so that no single court would be overburdened. Thus, to the extent that volume of litigation is a relevant factor in deciding if specialized courts should be established, the smaller but more concentrated customs and patent caseload might militate more strongly in favor of a specialized court, while the larger but more dispersed environmental caseload would not.

${ }^{27}$ Id. B-63 (response of the General Services Administration). 
these matters. Rather, the question is essentially one of staffing, workload, and efficient judicial allocation of functions. ... .

Like other special fields of the law, environmental matters involve highly specialized and intricate questions which could be adjudicated more efficiently by courts with expertise acquired from continual application of environmental statutes and regulations to technically complex issues. ... [A] Ithough existing federal courts can intellectually grasp the subject matter, given enough time and effort, to continue to burden general courts with the increasing volume of complex and technical environmental cases would interfere with existing priorities and aggravate the pressures of overcrowded dockets. $^{28}$

Others disagree that this sort of expertise would be a benefit. The most famous stand against specialized courts was written by Simon Rifkind. His thesis was that the "expertise" required in the judicial process is not technical know-how, but rather "the unique capacity to see things in their context." ${ }^{29}$ No "area" of law should be treated as if it existed in a vacuum; each "area" is "part and parcel of the whole body of our law." $30 \mathrm{Re}-$ ferring to the dangers involved in isolating patent law in the province of a specialized court, he noted:

In a democratic society the law, in the long run, tends to approach commonly accepted views of right and wrong. Thereby it continues its hold on the respect and allegiance of the people-in the last analysis its major sanction. Once you segregate the patent law from the natural environment in which it now has its being, you contract the area of its exposure to the selfcorrecting forces of the law. ${ }^{31}$

These views are not uniquely applicable to patent law. ${ }^{32}$ They apply, mutatis mutandis, to the environmental field as well, stemming "from a conception of the place and function of the law in a democratic society as the arbiter and mediator of conflicting

${ }^{28}$ Whitney II, supra note 11 , at 48.

${ }^{29}$ Rifkind, A Special Court for Patent Litigation? The Dangers of a Specialized Judiciary,

37 A.B.A.J. 425 (1951). But see H. FrIENDLY, FEDERAL JURISDICTION 156-57 (1973).

${ }^{30}$ Rifkind, supra note 29 , at 425 .

${ }^{31}$ Id.

${ }^{32}$ Rifkind fully recognized this. Id. 426 . 
social interests and demands. A one-function court cannot assist the law to discharge that responsibility."33

Whitney and Rifkind are talking past each other. Whitney speaks of the efficient allocation of resources, while Rifkind is concerned with the role and function of those resources themselves. Logically, Rifkind must be answered before Whitney is relevant. Whitney seems to have overlooked this point, and he never deals with Rifkind's concern about the role of the judiciary. The generalist character of judges is considered a major strength of our federal system. ${ }^{34}$ "In the long run we will get better decisions from judges with experience in all areas of law. Environmental judges would not have the impartial viewpoints of district court and circuit judges whose broad experience can be brought to bear on their cases." 35

Whitney does not confront this point directly. He is primarily concerned with the charge that the judges on the specialized court would be technicians incapable of deciding the more general, nontechnical questions arising in environmental cases. $\mathrm{He}$ argues, "There is simply no valid basis for assuming that environmental courts would be staffed by judges not competent to cope with so-called 'mixed' cases or with concepts derived from other branches of the law."36 While there probably exists a sufficient pool of qualified lawyers to staff a specialized court with generalists initially, the evolution of both the law and the judges is a major concern. If a large majority of the judges' time is spent on technical issues, they will almost inevitably lose touch with other areas of the law. Even a court that was once full of generalists could become myopic if its judges were exposed to only one corner of the law.

Lacking a discriminating analysis of the various judicial functions, the proponents of the "expertise" justification for an environmental court system seem reduced to the claim that the judge (at any level) must be able to understand the significance of the technical data before him. On this ground, all agree. ${ }^{37}$ The question at issue then becomes how such understanding can be supplied. Should a new court system be created to fill this need, or can the present structure be modified to accomplish the objective?

${ }^{33} \mathrm{Id}$.

34 Hines \& Nathanson, supra note 19, at C-12.

${ }^{35}$ REPORT, supra note 2, at B-10 (response of the Air Quality Subcommittee of the A.B.A.).

36 Whitney II, supra note 11 , at 39.

${ }^{37}$ See, e.g., Hines \& Nathanson, supra note 19, at C-12. 


\section{The Jurisdictional Problem}

A primary problem in attempting to establish a new court system is to define the system's jurisdiction. It is a problem which the proponents of an environmental court ultimately have failed to solve in any satisfactory manner. The comments received by the Attorney General's office indicated a widespread fear that establishment of an environmental court would result in "serious jurisdictional problems with other federal courts." 38 Many disputes may have environmental aspects; ${ }^{39}$ the determination whether a case is "environmental" will depend on the precise issues raised, giving rise to the spectre of forum shopping. ${ }^{40}$ There is a real fear that

[a]ny court that would have exclusive jurisdiction of the environmental impact of any action or on matters falling within the ambit of certain environmental laws could and probably would end up with jurisdiction over all the actions of the [Civil Aeronautics] Board since almost any Board action could have an alleged environmental effect. ${ }^{41}$

The fear that an environmental court might decide many cases in which the environmental issues are minor appears to be firmly grounded in fact. It would hardly seem logical to denominate actions of the Comptroller of the Currency "environmental." Yet,

[a]s indicated by the recent case of Billings v. Camp, ... Civil Action No. 1366-72 (D.C. 1972) involving approval without an environmental impact statement by the Comptroller of the Currency of a national bank's application for a branch, almost any action by this agency or any other Federal agency could conceivably involve environmental matters. ... When an environmental matter is peripheral to the main issues of a case, such [environmental] court would be no better qualified

${ }^{38}$ REPORT, supra note 2, at V-4.

39. See, e.g., United States v. Students Challenging Regulatory Agency Procedures, 412 U.S. 669 (1973), where plaintiffs sought to enjoin freight rate increases allowed by the Interstate Commerce Commission to certain railroads on the ground that the increases would discourage the use of recycled materials and would thereby be injurious to the environment. The Supreme Court held that the district court lacked jurisdiction to enjoin the increases.

${ }^{40}$ REPORT, supra note 2 , at V-5.

${ }^{41}$ Id. B-19 (response of the Civil Aeronautics Board). 
-and may be less qualified-to decide the case than another Federal court would be. ${ }^{42}$

The chief advocate of the position that environmental jurisdiction can be properly defined is probably Professor Whitney. His argument is that it may seem impossible to define precisely what an "environmental" case is, but the courts have been defining it successfully for a few years now.

Just as there is a common identifying thread permeating the diverse litigation before the Court of Claims, there similarly is a common thread permeating environmental litigation. . . . Cases arising under ... the National Environmental Policy Act (NEPA), the Clean Air Act, the Federal Water Pollution Control Act, the Noise Control Act, the Resource Recovery Act, and the Coastal Zone Management Act are readily identifiable as environmental litigation. In the case of citizens' suits commenced pursuant to federal environmental statutes providing for them, the environmental aspect similarly is apparent. ${ }^{43}$

He argues that since the courts now determine which agency actions constitute major federal actions affecting the environment, for NEPA purposes, it can hardly be impossible to identify cases appropriate for adjudication by an environmental court. ${ }^{44}$ In fact, the Environmental Protection Agency, the Council on Environmental Quality, and the Land and Natural Resources Division of the Department of Justice seem to have determined their respective jurisdictions without insuperable difficulties. ${ }^{45}$

Whitney's argument is open to sharp criticism. He appears to have overlooked a major logical gap: judgments about what is "environmental" may be perfectly adequate for one purpose but fail totally when the context shifts. It might be reasonable to allow the Environmental Protection Agency to rough out a determination of its own jurisdiction, since the courts of appeals will be alert to keep the agency within reason and statute. But the same looseness in the definitional matrix might be intolerable in an environmental court. Supreme Court review is hardly a confidence-inspiring method of keeping the court within

${ }^{42} \mathrm{Id}$. B-57 to -58 (response of the Federal Home Loan Bank Board) (citation omitted).

${ }^{43}$ Whitney II, supra note 11 , at 40 (footnotes omitted).

${ }^{44}$ Id. 40-41.

${ }^{45}$ Id. 41. 
bounds. ${ }^{46}$ And the standard doctrine of federal law is that federal courts have the power to determine whether they actually have jurisdiction over a case. ${ }^{47}$ A finding that the court has jurisdiction over the subject matter of a suit is res judicata of the issue, if the question was actually litigated and expressly decided.48 Thus, uncorrected jurisdictional "mistakes" may gradually extend the scope of the court well beyond its statutory limits. It is therefore imperative that a court's jurisdiction be more rigidly defined than that of an agency.

The jurisdictional problem cannot be brushed aside by Professor Whitney's arguments, cogent though they may be. Other problems also remain, such as determining the point at which a tangential or peripheral environmental issue in a pending case becomes sufficiently important to suggest that the case be litigated in an environmental court. As this point is reached, it becomes necessary to decide whether it is desirable that "mixed" cases, even ones with a significant environmental facet, be decided by specialized courts.

\section{IMPLICATIONS}

The problems discussed above apply with different force to the three environmental court models proposed by the Attorney General. ${ }^{49}$ The general jurisdiction model ${ }^{50}$ runs squarely into the definitional problem. ${ }^{51}$ Until it can be resolved, this model is infeasible. The second model, a new court to review all orders of federal agencies affecting the environment, ${ }^{52}$ runs into overbreadth problems. Almost anything can have environmental consequences. $^{53}$ In addition, the new court might "ignore social-economic considerations with narrow attention to scientific and technical details ...."54 If it exercised the same limited scope of review of substantive agency decisions that courts of

${ }^{46} C f$. Griswold, supra note 10 , at 1156 (using this as an argument for creating a new appellate body in the tax area).

${ }^{47}$ C. Wright, Law of Federal Courts $\$ 16$, at 50 (2d ed. 1970).

${ }^{48} I d$. 51. Exceptions to this rule exist when the policy in favor of finality of judgments is outweighed by other factors. For example, if a federal statute vests exclusive jurisdiction of a particular kind of case in the federal courts, a determination by a state court that it has jurisdiction will not be regarded as res judicata. Id.

${ }^{49}$ See text accompanying notes 5-8 supra.

50 This entails establishment of a court to hear all cases deemed to be "environmental", see text accompanying note 5 supra; REPORT, supra note 2, at V-1.

${ }^{51}$ See text accompanying notes $38-48$ supra.

${ }^{52}$ Text accompanying note 6 supra; REPORT, supra note 2, at V-2.

${ }^{53}$ See text accompanying note 42 supra.

5 REPORT, supra note 2, at B-8 (response of the American Bar Association). 
appeals presently do, its significance would be unclear. ${ }^{55}$ This model, in effect, shades into the general questions and debate regarding the establishment of a general administrative court.56 And in any case, it would do nothing at all to help trial courts.

The third model, an environmental court to review orders of designated federal agencies, ${ }^{57}$ would avoid the jurisdictional problems of the first model and the overbreadth worries of the second. The mere delineation of jurisdictional boundaries does not, of course, make this or any model a desirable one overall. In addition to failing to address problems at the trial level, this proposal "would sacrifice much of the rationale for creating an environmental court. It would leave environmental issues which arise under other statutes to be decided by the general Federal Courts." 58 Finally, this model would tend to increase the nonuniformity of the law by adding, in effect, an "Eleventh Circuit."

It cannot be denied that the technical nature of many environmental cases has caused the courts great concern. ${ }^{59}$ There is little reason to believe that the problems encountered to date will subside. Nevertheless, the establishment of a specialized environmental court does not seem desirable. The uncertain benefits of such a court are not sufficient to override its countervailing features. The remainder of the Comment will explore alternative solutions to the problems which courts face today in dealing with environmental cases.

\section{Proposals For Change}

\section{A. The Courts of Appeals}

The primary function of the courts of appeals in environmental cases is to review the administrative process. ${ }^{60}$ The courts have what is basically a supervisory function:

In the exercise of the court's supervisory function, full allowance must be given for the reality that agency matters typically involve a kind of expertise-"some-

${ }^{55}$ Id. B-33 (response of the Council on Environmental Quality). But cf. text accompanying note 28 supra (expertise). 153-71.

${ }^{56}$ See, e.g., Hines \& Nathanson, supra note 19; $f f$. H. FriendLY, supra note 29, at

${ }^{57}$ Text accompanying note 7 supra; REPORT, supra note 2 , at V-2.

58 RePORT, supra note 2, at B-35 (response of the Council on Environmental Quality).

:9 See, e.g., Ohio v. Wyandotte Chemicals Corp., 401 U.S. 493, 502-05 (1971); text accompanying note 28 supra.

${ }^{60}$ See Leventhal, Environmental Decisionmaking and the Role of the Courts, 122 U. PA. L. Rev. 509, $511-15$ (1974). 
times technical in a scientific sense, sometimes more a matter of specialization in kinds of regulatory programs." Nevertheless, the court must study the record attentively, even the evidence on technical and specialist matters, "to penetrate to the underlying decisions of the agency, to satisfy itself that the agency has exercised a reasoned discretion with reasons that do not deviate from or ignore the ascertainable legislative intent." . . . Finally, if satisfied on these points, the court sustains an agency even though its findings are "of less than ideal clarity, if the agency's path may reasonably be discerned." The court is not to make its own findings $\ldots$. $^{61}$

The court is not to evaluate the technical accuracy or validity of the agency's factual analysis, as it would in a de novo action. Rather, the court is to ascertain whether the agency has stayed within the bounds of its statutory discretion. ${ }^{62}$ If the court is unable to penetrate scientific language, the best solution is to remand to the agency. ${ }^{63}$

Within this structure, the main "expertise" required of the courts of appeals is that of the law of judicial review. Going beyond that requires entry into the morass of arguments concerning specialized, or "expert," appellate courts. ${ }^{64}$ Two federal appellate judges have questioned the wisdom of establishing an environmental court filled with expertized judges. Judge Harold Leventhal of the District of Columbia Circuit recently wrote:

The desirability of a specialist [environmental] court has been the subject of active debate recently .... I am skeptical of the proposal. ... .

A second criticism is based on the view of the appel-

late judge's role .... Review to ensure balance, coupled with restraint on the part of the reviewer, requires a

${ }^{61} I d .511$ (footnotes omitted).

${ }^{62}$ Citizens to Preserve Overton Park, Inc. v. Volpe, 401 U.S. 402 (1971); NLRB v. Nevada Consol. Copper Corp., 316 U.S. 105 (1942). See generally 4 K. Davis, Administrative LAw Treatise § 29.11 (1958); Leventhal, supra note 60, at 511-12; Nathanson, Proposals For An Administrative Appellate Court, 25 AD. L. REv. 85 (1973).

${ }^{63}$ See, e.g., Kennecott Copper Corp. v. EPA, 462 F.2d 846 (D.C. Cir. 1972); $c f$. Environmental Defense Fund, Inc. v. Ruckelshaus, 439 F.2d 584 (D.C. Cir. 1971). But see Freedman, The Uses and Limits of Remand in Administrative Law: Staleness of the Record, 115 U. PA. L. REV. 145 (1966) (questioning the indiscriminate reliance on this technique).

${ }^{64}$ The more general question of the desirability of having all appellate judges expert in the substantive matters of the agencies they supervise is well beyond the scope of the Comment. See Nathanson, supra note 18, at 999-1001. See also H. FRIENDLY, supra note 29 , at $182-89$. 
generalist who can penetrate the scientific explanation underlying a decision just enough to test its soundness. A specialist whose attention was directed exclusively to environmental issues would tend to intrude his own judgment on the issues, thereby coopting the discretion of the agency. ${ }^{65}$

Judge James Oakes, of the Second Circuit, is in accord: "[T]he current system of review by generalist judges already allows for the consideration of the best technical expertise in the various areas of environmental concern." 66

There has been no effective rebuttal to these ideas regarding the function of the appellate level of review. ${ }^{67}$ Professor Whitney, in his defense of the proposal to create an environmental court system, ${ }^{68}$ places most of his emphasis on the potential to define the jurisdiction of such a system. Although Whitney cites Justice Douglas' dissenting opinion in Ohio v. Wyandotte Chemicals Corp. ${ }^{69}$ in support of his argument that specialized knowledge is required by judges in environmental cases, ${ }^{70}$ this does not specifically concern the need for technical expertise at the appellate level. Wyandotte Chemicals was a case arising out of the Court's original jurisdiction, and the Justice's remarks on the need for expertise must be read in that light.

Under section 102(2) of NEPA, ${ }^{71}$ which directs the courts of appeals to assess the adequacy of environmental impact statements, remand has been the answer to agencies that cannot reduce their jargon to English. ${ }^{72}$ And, as Judge Leventhal points out, appellate courts may gain access to technical experts in various ways. ${ }^{73}$ In other words, it is possible to keep the advantages of generalist courts and still plug in whatever technical input those courts feel they need. ${ }^{74}$ Furthermore, the court is always

${ }^{65}$ Leventhal, supra note 60 , at 517-18 (citations omitted).

${ }^{66}$ Oakes, Developments in Environmental Law, 3 ENv. L. REP. 50001,50012 (1973).

${ }^{67}$ Dean Griswold, in championing the idea of an appellate tax court, stressed the need for uniformity of law rather than expertise. Griswold, supra note 10.

${ }^{68}$ Whitney II, supra note 11 .

${ }^{69} 401$ U.S. 493, 510-12 (1971) (Douglas, J., dissenting). Cf. the majority's statement: "The notion that appellate judges, even with the assistance of a most competent Special Master, might appropriately undertake at this time to unravel these complexities is, to say the least, unrealistic." Id. at 504.

${ }^{70}$ Whitney II, supra note Il, at 42 .

7142 U.S.C. § 4332(2) (1970).

${ }^{72}$ E.g., Environmental Defense Fund, Inc. v. Ruckelshaus, 439 F.2d 584 (D.C. Cir. $1971)$; cf. Freedman, supra note 63.

${ }^{73}$ Leventhal, supra note 60 , at 550-55.

${ }^{74}$ Id. 550 . 
free to require counsel to submit explanations of technical matters. ${ }^{75}$

In light of the nature of the appellate judicial process and the availability of various methods for providing appellate courts with technical information and advice, the principle of Ockham's Razor $^{76}$ seems determinative; there is not sufficient justification for creating a specialized environmental court of appeals. Reform efforts should focus instead on the trial courts, where the need for comprehension of complex data is most acute.

\section{B. The Trial Courts}

Several recently enacted federal environmental statutes authorize citizens to bring civil actions against any person alleged to be in violation of either an effluent (or other environmental) standard or limitation or any order issued by the administrator of the relevant environmental agency. Actions may also be brought against the administrator himself when there is an alleged failure on his part to perform any nondiscretionary duty. ${ }^{\mathbf{7 7}}$ Jurisdiction is vested in the district courts. The traditional model of environmental litigation involved appellate review of the decision of an administrative agency which had already made the requisite technical findings; now, the district courts must embroil themselves in the technical controversy. The Supreme Court made this duty explicit in Washington v. General Motors Corp. ${ }^{78}$ Eighteen states sought to invoke the Court's original jurisdiction in an action to enjoin the four major auto manufacturers' violation of federal antipollution laws. The Court declined to exercise its jurisdiction, and remanded the plaintiffs to their respective district courts. Those district courts will have to hear evidence to determine whether specific technical standards have been violated, and they will not have any presumptively correct administrative findings to ease their task.

Another case which raises the problem of technical factual disputes involved a local citizens group's declaratory and injunctive action seeking to prevent the defendants from authorizing further municipal sewer hookup permits. It was alleged that issuing such permits would result in discharges that would affect the

${ }^{75}$ See id. 545-46. See also Leventhal, Cues and Compasses for Administrative Lauyers, 20 AD. L. REv. 237 (1968).

${ }^{76}$ Generally: Do not multiply entities beyond that number which is absolutely necessary to the solution of the problem.

${ }^{77}$ E.g., Water Pöllution Control Act, 33 U.S.C. $\S 1365$ (Supp. II, 1972); Clean Air Act, 42 U.S.C. $\S 1857 \mathrm{~h}-2(1970)$.

${ }^{78} 406$ U.S. $109,114,116$ (1972). 
water supply of the Potomac River. The court, ruling on a motion to dismiss, held that a cause of action had been stated: the complaint alleged that allowing further permits would increase the discharge into the water and thereby violate the applicable water quality standards. ${ }^{79}$ The case is not reported further, but it is clear that if such an action were heard on the merits, both sides would be expected to produce scientific data for the court to evaluate.

In the environmental field there will thus be a number of cases in which the district courts will have to weigh and evaluate conflicting scientific evidence. The question remains how justice to the individual litigants and compliance with federal law can best be assured.

\section{The Super-Clerk}

One proposal that has been advanced is that "expert" law clerks should be appointed to assist judges in the resolution of technical factual controversies. Judge Charles Wyzanski experimented with this approach in United States $v$. United Shoe Machinery Corp. ${ }^{80}$ an antitrust suit which raised complex economic issues. His experience with his clerk, Dr. Carl Kaysen, a professor of economics at Harvard, is quite instructive.

Judge Wyzanski found the use of an expert clerk quite helpful. Dr. Kaysen's analysis of the evidence presented on the record enabled the Judge to ask more probing questions of counsel and the witnesses and more easily to understand the factual questions in dispute. Judge Wyzanski concluded, "I have no doubt that $I$ benefited and in my opinion justice was served by the appointment of Mr. Kaysen." "11 Nevertheless, the Judge was not certain that he would be willing to repeat the experiment. He expressed the fear that the clerk, by reason of his expertise in a technical area beyond the competence of the judge, could exert an undue influence on the decision. In effect, the clerk, rather than the judge, would be deciding the case.

Dr. Kaysen himself has suggested that there are two strong reasons why an economist should not again be made a judge's law clerk. ${ }^{82}$ First, it is unfair to the parties, who have no chance to attack or rebut the clerk's technical analysis. Second, there is a

${ }^{79}$ Montgomery Environmental Coalition v. Fri, 366 F. Supp. 261 (D.D.C. 1973).

${ }^{80} 110$ F. Supp. 295 (D. Mass. 1953), aff'd, 347 U.S. 521 (1954).

${ }^{B 1}$ Letter from Judge Charles Wyzanski to Bethuel Webster, Oct. 3, 1950, reprinted in Webster \& Hogeland, The Economist in Chambers and in Court, 1958 A.B.A. ANTITRust SEction $50,67$.

${ }^{82}$ Kaysen, An Economist as the Judge's Law Clerk in Sherman Act Cases, id. 43. 
possibility that the judge will not be able to make an independent evaluation of the clerk's reports.

These arguments are compelling. ${ }^{83}$ The use of expert clerks, while lending much needed expertise to the judicial process, creates a substantial risk that judges will abdicate their function to their clerk. The parties to the litigation will effectively be denied the opportunity to cross-examine a very influential witness upon whom the judge is likely to rely heavily. Thus, while the "super-clerk" proposal would provide the expertise needed at the trial court level in environmental cases, there remain serious doubts about the overall wisdom of implementing this plan.

\section{The Non-Partisan Court-Called Expert}

A second proposal which has been suggested is the appointment by the court of an expert witness. ${ }^{84}$ This proposal meets one of the objections raised against the use of expert clerks: the expert will be available to both parties for crossexamination. However, a number of problems would remain.

If the witness draws factual conclusions in an area beyond the judge's competence, he would essentially be deciding issues in the case. That is not the proper role of a witness. Witnesses are supposed to present testimony to the adjudicator; they are not supposed to become the adjudicator. Abdication of decisionmaking power to the witness would thus be a problem. If, on the other hand, the judge can understand the scientific aspects of the case, albeit only with the expert's help, he could presumably also understand the facts with the aid of experts called by the parties. In that case, the court-called expert would be superfluous. In fact, his superfluity even extends to cases whose technical aspects the judge cannot understand: there is no reason that the judge will understand his explanations better than those of experts called by the parties.

Furthermore, considerable debate ${ }^{85}$ about the advisability of

${ }^{83}$ See generally Webster, The Use of Economics Experts as Witnesses in Antitrust Litigation, 17 ReCoRd of N.Y.C.B.A. 456 (1962). But of. Leventhal, supra note 60 , at 553-54 (supporting an appellate court's use of a super-clerk in environmental cases).

${ }^{84}$ This approach was used by Judge William Coleman in a complex patent infringement suit. With the consent of both parties, he appointed an expert of his own to read and evaluate the evidence. The expert gave his opinions in open court and was subject to cross-examination by the parties and the judge. The judge felt that the expert was "of material aid in clarifying the intricate mechanism of the two devices, and the precise questions at issue." Specialty Equip. \& Mach. Corp. v. Zell Motor Car Co., 96 F. Supp. 904, 910 (D. Md. 1951), rev'd on other grounds, 193 F.2d 515 (4th Cir. 1952), on remand, 113 F. Supp. 161 (D. Md. 1953), discussed in W'ebster, supra note 83, at 460-61.

${ }^{85}$ Compare Griffin, Impartial Medical Testimony: A Trial Lauyer in Favor, 34 TEMP. L.Q. 402 (1961) (favoring the use of such experts), with Levy, Impartial Medical Testimony -Revisited, id. 416 (opposed). 
court-appointed witnesses has focused on the question of the existence of "impartial experts" and "objective scientific facts." 86 It has been strenuously argued that neither economics ${ }^{87}$ nor medicine ${ }^{88}$ is an exact science and that an expert's testimony in these areas will therefore inevitably be colored by his own prejudices. If this argument has merit when economic and medical questions are at issue, it also has force in the environmental area, where questions of fact and policy are intimately interwoven.

\section{Masters}

A third method of injecting scientific expertise into judicial proceedings is the use of special masters, as provided for by rule 53 of the Federal Rules of Civil Procedure. Special masters have not often been used in federal environmental cases. ${ }^{89}$ Nevertheless, their use offers a potential solution to both the jurisdictional and the "expertise" problems in environmental cases, without creating a new judicial entity.

\section{a. The General Outline}

The district courts should be authorized ${ }^{90}$ to make wider use of special masters whenever the court feels that an issue of fact is beyond the scope of its technical expertise. The use of special masters avoids the major criticisms levied against the creation of an environmental court system, while meeting the need that the environmental courts were proposed to satisfy. ${ }^{91}$

Masters can be used in the federal courts "only when the issues are complicated"; non-jury cases, which most environmen-

${ }^{86}$ Cf. Ohio v. Wyandotte Chemicals Corp., 401 U.S. 493, 503-04 (1971):

We already know, just from what has been placed before us on this motion ... that the scientific conclusion that mercury is a serious water pollutant is a novel one; that whether and to what extent the existence of mercury in natural waters can safely be tolerated is a question for which there is presently no firm answer.... Indeed, Ohio is raising factual questions that are essentially ones of first impression to the scientists.

${ }^{87}$ Webster, supra note 83.

${ }^{88}$ Levy, supra note 85.

${ }^{89}$ One recent, notable exception occurred in the Supreme Court. Although the parties settled the case (which came under the Court's original jurisdiction), the Court ordered the parties to pay $\$ 50,000$ to $R$. Ammi Cutter, who had served as a special master in the case. N.Y. Times, Oct. 31, 1974, at 44, col. 1-2 Cf. Ohio v. Wyandotte Chemicals Corp., 401 U.S. 493, 511 (1971) (Douglas, J., dissenting).

90 To the extent that wider use of special masters in environmental cases would be inconsistent with present law regarding their use, see text accompanying notes 92-104 infra, the proposed authorization could be made by appellate decision, Supreme Court rulemaking, or Congressional action.

${ }^{91}$ Several of the groups and agencies responding to the Attorney General's request to comment on the environmental court proposals, see note 9 supra, included the availabil- 
tal actions are, can be referred to a master "only upon a showing that some exceptional condition requires it." "92 The limitation has been rather strictly enforced. The leading case is the Supreme Court's decision in La Buy v. Howes Leather Co. ${ }^{93}$ which held that simple docket congestion is not the sort of "exceptional condition" warranting references to masters. The master can be appointed only to help the court in a case where such help is actually needed. He is an "instrument for the administration of justice [to be employed by the court] when deemed by it essential."94

Thus, the use of masters to aid the judge in carrying out his judicial function is permitted as long as the master does not in fact assume the judicial role. ${ }^{95}$ The fear of abdication to masters of the judicial function exclusively reserved to the judiciary by the Constitution ${ }^{96}$ is the primary objection to their use. Whatever intrinsic force this objection may possess is, of course, not limited to environmental cases.

A master's findings of fact in a non-jury action must be accepted by the court "unless [they are] clearly erroneous."97 The Federal Rules thus explicitly recognize that the "expert's"

ity of special masters as a reason why a new judicial entity was not necessary.

The I.C.C. was generally opposed to the environmental court proposals. It suggested that "if experience should show that the existing courts are incapable of adequately handling the scientific matters in environmental cases, then legislative provisions authorizing more liberal use of special masters may be desirable." REPORT, supra note 2, at B-70 (response of the Interstate Commerce Commission). The General Counsel of the Treasury specifically adverted to the use of rule 53 to alleviate any possible problems of technical complexity. He noted that the appointment of masters under the rule "would provide any needed expertness without removing the decision on other points in litigation from the existing courts." Id. B-97 (response of the General Counsel of the Treasury).

${ }_{92}$ FED. R. CIv. P. 53(b). The rule is of ancient lineage, and is derived from former equity practice. See Kimberly v. Arms, 129 U.S. 512, 524-25 (1889) (Field, J.) ("[I]t has always been within the power of a court of chancery with the consentof [the] parties, to order . . . a reference [to a master] .... The power is incident to all courts of superior jurisdiction."). Subject to the exceptions stated in rule 81 (applicability of the Federal Rules generally) and to the special problems raised by rule 71A (condemnation of property), rule 53 now applies to all civil suits. 5A J. MOORE, Federal Practice IfI 53.02[1-2], 53.14[2] (2d ed. 1974). In addition, "[c]ourts have (at least in the absence of legislation to the contrary) inherent power to provide themselves with appropriate instruments required for the performance of their duties. ... This power includes authority to appoint persons unconnected with the court to aid judges in the performance of specific judicial duties ...." Ex parte Peterson, 253 U.S. 300, 312 (1920) (Brandeis, J.).

93352 U.S. 249 (1957).

${ }^{94}$ Ex parte Peterson, 253 U.S. 300, 312 (1920).

95 La Buy v. Howes Leather Co., 352 U.S. 249, 256 (1957); Hartford-Empire Co. v. Shawkee Mfg. Co., 5 F.R.D. 46 (W.D. Pa. 1946).

${ }^{96}$ Kaufman, Masters in the Federal Courts: Rule 53, 58 Colum. L. Rev. 452, 453 (1958).

97 FED. R. Civ. P. 53(e)(2). 
opinion, in a factual area beyond the judge's perceived competence, will actually have the status of a decision. Both parties will have the opportunity to see the master's findings, to file their objections with the court, and to challenge to findings on appeal.

Since the judges can use masters only as aids and not as replacements, a blanket provision for systematically referring a particular type of case-such as all environmental cases-would not be permitted..$^{98}$ In $M c$ Cullough $v$. Cosgrove,$^{99}$ for example, the order of reference had recited that the judge to whom the cases were assigned was unable to try it because of illness; that all the parties desired an early trial; that no other judge was available; that the calendar of the court was congested; and that the cases had been pending for a long time and were complex patent suits. ${ }^{100}$ Yet the Supreme Court vacated the district court's reference in a per curiam opinion, citing Los Angeles Brush Manufacturing Co. v. James. ${ }^{101}$ The James case was one in which a district court had treated patent cases as a class, referring them generally to a master in order to unclog its docket. Although the Supreme Court refused mandamus to vacate the reference, ${ }^{102}$ the Court made it quite plain that, with the possible exception of the necessity of giving criminal cases priority, there were no grounds to justify reference to a master simply because a case fell within a given class. ${ }^{103}$

In a later case, Judge Evans of the Seventh Circuit articulated the general policy underlying the Supreme Court's statement:

The District Court seemed to labor under the impression that the words "exception" and "exceptional" as used in ... rule [53(b)], are elastic terms, with it the sole judge of their elasticity. Such a construction, we cannot accept.

Litigants are entitled to a trial by the court, in every suit, save where exceptional circumstances are shown. ... Likewise, the litigants prefer, and are entitled to, the decision of the judge of the court before whom the suit is brought. Greater confidence in the outcome of the

${ }^{98}$ Kaufman, supra note 96 , at 454 .

${ }^{99} 309$ U.S. 634 (1940).

${ }^{100}$ 5A J. MOORE, supra note 92, I 53.05[2], at 2942.

101272 U.S. 701 (1927).

102 Mandamus was refused on the ground that there had not been a sufficient showing of abuse of discretion. Id. at 708.

${ }^{103}$ Id. at 706-08. 
contest and more respect for the judgment of the court arise when the trial is by the judge. ${ }^{104}$

This language may overstate the case when applied to a court that must decide purely technical environmental fact questions. The judge presumably refers only those issues which he determines are beyond his competence. It is hard to see how the parties would have greater confidence in the outcome if the judge decided those factual questions himself. It should be stressed that the proposal contemplates that questions will be referred, not whole cases.

It is still the law that reference may only be made when exceptional circumstances warrant it. A case cannot be referred merely to relieve a congested court calendar. Neither can a case be referred solely on the ground that there are complex factual questions at issue; a judge must at least be familiar with the complicated and technical aspects of a case in order to rule on the legal issues involved. Nevertheless, when there are disputed factual issues which a special master, because of his training or experience, is unquestionably more competent than the court to decide, technical complexity is a relevant consideration in determining whether reference is proper. ${ }^{105}$ Much of the environmental litigation at the district court level may involve complex technical questions demanding specialized expertise. Although a blanket reference policy for such cases cannot be justified, many of these environmental cases may individually warrant reference on their own account.

\section{b. Jurisdiction and Expertise}

One of the main objections to establishing an environmental court system is the difficulty (at the trial court level) of defining its jurisdiction. ${ }^{106}$ Under the proposed plan, this problem could not arise. The cases, as a whole, will still be tried by the district courts. Those courts, in the exercise of their sound discretion, may refer one or more factual issues to a special master. Such piecemeal reference is explicitly authorized by the federal rules. ${ }^{107}$ By leaving the question of what issues need be referred

${ }^{104}$ Adventures in Good Eating, Inc. v. Best Places to Eat, Inc., 131 F.2d 809, 814, 815 (7th Cir. 1942).

${ }^{105}$ Fraver v. Studebaker Corp., 11 F.R.D. 94 (W.D. Pa. 1950); Kaufman, supra note 96 , at 457 .

${ }^{106}$ See text accompanying notes 38-48 supra.

${ }^{107}$ FED. R. Civ. P. 53(c). See 5A J. MOORE, supra note 92, I 53.05[2], at 2959-62 (giving examples). 
to the discretion of the court involved, no formal, general rule of jurisdiction need be laid down.

A similar analysis applies to the objection that a specialized court will be unsuited to decide the general statutory and policy questions involved in environmental litigation. ${ }^{108}$ Under the proposed plan, cases do go before generalist courts, and those courts remain free to apply their accumulated judicial wisdom to any and all questions at issue. Even if all technical issues are referred, independent statutory and policy questions remain, and the court retains the power to dispose of the ultimate issues in the case.

\section{Conclusion}

It is generally agreed that the establishment of an environmental court system would create more problems than it would solve. Nevertheless, even the most ardent critics of the proposal recognize the need to give the present district courts some way to evaluate the technical scientific data involved in many environmental cases. Several alternative proposals have been considered, and all foundered upon the same rock: if the resolution of factual issues is beyond the court's competence, then the advisor will effectively be assuming the judicial function of deciding the case.

This fact should not be disguised. It should be acknowledged and dealt with openly within the present judicial framework. Through the increased use of special masters, federal courts can obtain nonpartisan expertise to evaluate the factual scientific material presented in environmental litigation. Because reference of a question to such a master is left to the sound discretion of the court, there is no need to grapple with the abstract, unsolvable question of just what is an "environmental" case. Finally, preservation of the present judicial structure allows retention of the accumulated benefits of having generalist judges deciding questions of statutory construction and policy.

${ }^{108}$ See text accompanying notes 28-37 supra. 